\title{
RANCANG BANGUN STERILISATOR BAKTERI PADA UDARA BERBASIS MIKROKONTROLLER ARDUINO UNO
}

\author{
St. Fatimang \\ Teknik Elektromedis, Politeknik Kesehatan Muhammadiyah Makassar Email:sitti.fatimang@gmail.com
}

\begin{abstract}
(). (1) (-)
Abstrak

Penelitian ini sebagai pengembangan teknologi tepat guna dengan menggunakan sistem automatisasi dan pengembangan teknologi kesehatan khususnya dibidang sterilisasi kesehatan dengan membuat sebuah alat sterilisator bakteri dengan menggunakan sistem pengisapan dan pembuangan blower dan melakukan evaluasi dampak penggunaan sterilisator bakteri yang terkandung dalam udara pada ruangan pensterilan Uji coba alat Sterilisator Bakteri Udara ini dilakuakan di RSIA St. Khadijah III, Dan penempatkan alat tersebut di Ruang Perawatan dan Ruang Bedah. Selama proses pensterilan berjalan juga dilakukan pengukuran Tegangan Keluaran pada lampu Ultra Violet yang digunakan dan berdasarkan analisa sttistik rata-rata waktu yang dihasilkan dari penyettingan waktu 30 menit adalah 29,26 menit, ini menunjukkan penurunan dari waktu yang ditentukan yaitu koreksi sebesar 0,74 menit. Dengan kesalahan (error) sebesar 0,74\%. Dan penyettingan waktu 60 menit adalah 59,42 menit ,ini menunjukkan penurunan dari waktu yang ditentukan yaitu koreksi sebesar 0,57 menit. Dengan kesalahan (error) sebesar 0,96\%. Hasil dari penelitian ini diharapkan dapat menjadi alat yang bermanfaat untuk ruang operasi sehingga udara di ruangan tersebut steril dari bakteri dan kuman dan menjadi pembanding untuk pengembangan alat sterlisator selanjutnya.
\end{abstract}

Kata Kunci : Sterilisator, Blower, Mikrokontroller Arduino

\section{Pendahuluan}

Pada Pesawat sterilisator yang menggunakan cahaya ultraviolet sebagai media system sterilisatornya mempunyai proses yang sangat sederhana. Pada pesawat ini digunakan sebuah atau beberapa buah lampu ultraviolet sebagai komponen utamanya.prinsip pembangkitan sinar ultraviolet sama dengan prinsip lampu tL, perbedaanya tergantung pada gas yang digunakan : seperti diketahui bahwa ultraviolet mempunyai suspensi yang tinggi,sehingga sinar ultraviolet ini dapat membunuh kuman dan bakteri yang bercampur dengan udara

Pada rumah sakit sering dilakukan sterilisasi pada peralatan-peralatan yang digunakan, ruangan yang akan digunakan apalagi bila ruangan tersebut akan digunakan untuk operasi.

Peralatan UV Lamp sterilisator digunakan untuk sterilisasi ruangan dengan cara menyinari ruangan dengan cahaya UV dengan durasi hingga 4 jam. Cahaya UV ini sangat berbahaya bagi manusia karena dapat mengakibatkan kanker kulit dan kebutaan. Sehingga perlu dilakukan pengontrolan dengan memberikan kesempatan kepada operator untuk meninggalkan ruangan dan indikator bahwa peralatan sedang bekerja. Dikarenakan radiasi yang di timbulkan oleh sinar UV maka penulis berinisiatif ingin melakukan pengembangan dengan membuat alat "sterilisator bakteri yang terkandung dalam udara berbasis mikrokontroller arduino" pada alat tersebut yaitu menempatkan lampu UV di dalam box sehingga pancaran sinar dari lampu UV tidak ada kontak langsung ke petugas yang mengoperasikan alat tersebut disini penulis juga menambahkan dua buah blower untuk menghisap dan melepaskan udara sehingga sirkulasi udara terus berganti sampai udara tersebut steril dari bakteri dan kuman[1][2].

Proses sterilisasi yang lama mengakibatkan pendeknya umur dari lampu. Umumnya lampu UV memiliki umur pemakaian hingga 3000 jam. Setelah itu kemungkinan lampu akan rusak atau lemah sehingga tujuan sterilisasinya tidak tercapai

\section{Tinjauan Pustaka}

\section{Sterilisator bakteri yang terkandung dalam udara}

Udara merupakan zat yang paling penting dalam memberikan kehidupan dipermukaan bumi ini.Selain itu, oksigen, udara juga berfungsi sebagai alat penghantar bunyi dan suara, pendingin benda benda panas dan dapat menjadi media penyebaran penyakit pada manusia Udara merupakan campuran mekanisme dari berbagai 
macam gas, komposisi normal udara terdiri dari gas nitrogen $78,1 \%$ oksigen $20,9 \%$ dan karbondioksida 0,03 sementara selebihnya Berupa argon, neon, krypton senon,helium, dan lain lain. Udara juga mengandung uap air, debu, bakteri, spora dan sisa tumbuh-tumbuhan.\& masalah pengotoran udara sudah lama menjadi masalah kesehatan pada masyarakat, terutama pada ruang lingkup rumah sakit terkhususnya ruang perawatan .

peralatan kesehatan merupakan salah satu faktor yang dapat menunjang dalam upaya penyelenggaraan pelayanan kesehatan bagi masyarakat, karena itu untuk meningkatkan pelayanan kesehatan yang berkesinambungan perlu didukung dengan alat yang layak pakai Serta dapat berfungsi dengan baik, khususnya peralatan steilisator. [3]

\section{Mikrokontroler Arduino}

Arduino Uno adalah board mikrokontroler berbasis ATmega328. Uno memiliki 14 pin digital input / output (dimana 6 dapat digunakan sebagai output PWM), 6 input analog, resonator keramik $16 \mathrm{MHz}$, koneksi USB, jack listrik, header ICSP, dan tombol reset. Uno dibangun berdasarkan apa yang diperlukan untuk mendukung mikrokontroler, sumber daya bisa menggunakan power USB (jika terhubung ke komputer dengan kabel USB) dan juga dengan adaptor atau baterai[4][5].

Arduino Uno berbeda dari semua papan sebelumnya dalam hal tidak menggunakan FTDI chip driver USB-to-serial.Sebaliknya,fitur Atmega16U2 (Atmega8U2 sampai versi R2) diprogram sebagai konverter USB-toserial.Revisi 2 dari Uno memiliki resistor pulling 8U2 HWB yang terhubung ke tanah,sehingga lebih mudah untuk menggunakan mode DFU. Gambar 1 menunjukkan mikronktroller arduio uno.

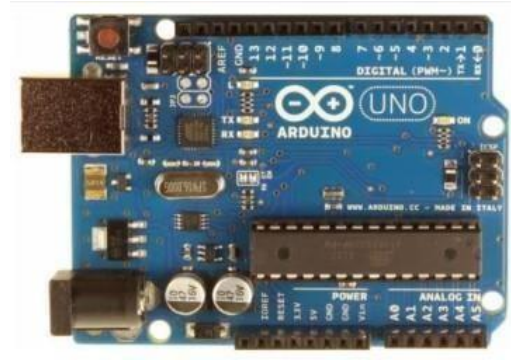

Gambar 1. Mikrokontroler Arduino

\section{Relay}

Relay adalah Saklar (Switch) yang dioperasikan secara listrik dan merupakan komponen Electromechanical (Elektromekanikal) yang terdiri dari 2 bagian utama yakni Elektromagnet (Coil) dan Mekanikal (seperangkat Kontak Saklar/Switch). Relay menggunakan Prinsip Elektromagnetik untuk menggerakkan Kontak Saklar sehingga dengan arus listrik yang kecil (low power) dapat menghantarkan listrik yang bertegangan lebih tinggi. Sebagai contoh, dengan Relay yang menggunakan Elektromagnet $5 \mathrm{~V}$ dan $50 \mathrm{~mA}$ mampu menggerakan Armature Relay (yang berfungsi sebagai saklarnya) untuk menghantarkan listrik 220V 2A.

Dibawah ini adalah gambar bentuk Relay dan Simbol Relay yang sering ditemukan di Rangkaian Elektronika.

Pada dasarnya, Relay terdiri dari 4 komponen dasar yaitu :

1. Electromagnet (Coil)

2. Armature

3. Switch Contact Point (Saklar)

4. Spring

\section{Lampu Ultra Violet}

Pengertian umum lampu ultra violet atau sering kali di sebut lampu UV, adalah produk lampu yang menghasilkan sinar ultra violet. Sinar ultra violet sendiri memiliki kateristik khusus yang dapat di aplikasikan dalam bidang yang sangat luas.

Sinar Ultra Violet sendiri berdasarkan panjang sinar gelobang dapat di klasifikasikan menjadi tiga tingkatan utama, semakin pendek gelombang sinar semakin kuat karakteristiknya. Pada umumnya tingkatan lampu UV disebut dengan UV-A kemudian UV-B dan UV-C.

1.Klasifikasi UV-A : panjang gelombang < 315 $380 \mathrm{~nm}$, contoh aplikasi jenis lampu UV ini misalkan lampu UV untuk mendekteksi uang asli atau palsu.

2. Klasifikasi UV-B : panjang gelombang < 280 $315 \mathrm{~nm}$, contoh aplikasi jenis lampu ini misalkan lemari penyimpanan peralatan media ( ada juga yang pakai jenis UV-A, biasa penyimpanan berupa kaca bening tampa peredam sinar ) 3.Klasifikasi UV-C : panjang gelombang $<280$ $\mathrm{nm}$, cohtoh aplikasi jenis lampu ini misalakan sterilisasi air untuk jenis UV-C paling kuat Setiap pengaplikasian tentu memerlukan perhitungan dan tehnis tertentu agar tercapai 
maksud dan tujuan serta perhitungan faktor keamanan.Dalam kaitan dengan bidang perikanan, pengolahan air, dan pengolahan limbah cair atau pengolahan air limbah pada umumnya, umumnya ada ada sitem yang sering digunakan, Lampu UV submersible, atau sering juga disebut lampu UV celup, dan lampu UV model pressure UV lamp, atau sering juga di sebut Lampu UV tabung

\section{Matodelogi Penelitian}

\section{Alur Proses Penelitian}

Metodologi yang digunakan dalam pengerjaan penelitian ini terbagi menjadi beberapa tahap seperti yang ditunjukkan pada gambar 2 tentang flow chart proses penelitian Pembuatan alat Sterilisator Bakteri :

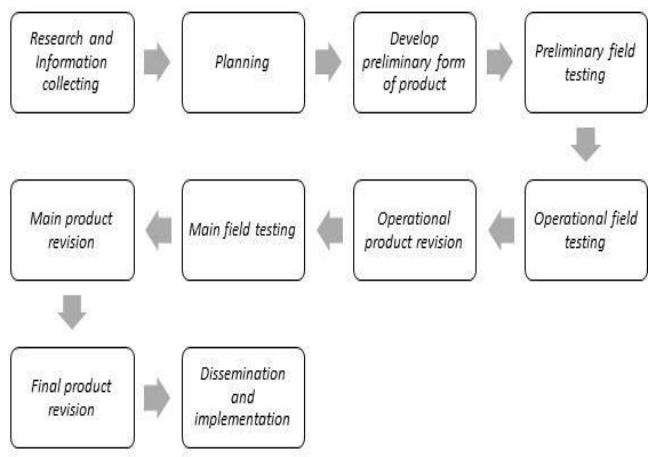

Gambar 2. Fow Chart proses penelitian

\section{Model Pengembangan}

Model yang digunakan dalam penelitian ini adalah model penelitian dan pengembangan atau Research and Development (R\&D) dan dilanjutkan dengan ekperimen. Model pengembangan dalam penelitian ini melalui tahap model konseptual, model teoritik, model hipotetik dan model final. Model konseptual adalah model yang bersifat analitis, yang menyebutkan komponen-kompone produk, menganalisis komponen secara rinci dan menunjukkan hubungan antar komponen yang akan dikembangkan. Model teoritik adalah model yang menggambarkan kerangka piker yang didasarkan pada teori teori yang relevan dan didukung oleh data empiric. Model hipotetik adalah model yang sudah mendapat masukan pakar dan praktisi melaalui focus group discussion (FGD). Model final ini adalah model yang sudah diuji coba empiric [6]. Penelitian dan pengembangan bertujuan untuk menemukan, mengembangkan dan memvalidasikan suatu produk [7]

\section{Tahap Pengembangan Model}

Model yang dikembangkan berdasarkan rekomendasi Borg dan Gail (1983 : 775) yang mengembangkan 10 tahapan model, sebagai berikut :

1. Penelitian dan Pengumpulan Informasi (Research dan Information collecting )

2. Penelitian ( Planning)

3. Mengembangkan bentuk awal dari produk

(Develop preliminary form of product)

4. Uji Lapangan awal (Preliminary field testing)

5. Revisi Produk Utama (Main Product

Revision)

6. Uji lapangan Utama (Main FieldTesting)

7. Revisi Produk Operasional (Operational Product Revision)

8. Uji Lapangan Operasional (Operational Field Testing)

9. Revisi Produk Akhir (Final Product Revision) 10. Desiminasi dan Implementasi (Dessemination and Implementation)

\section{Blok Diagram Alat}

Perancangan alat Sterilisator Bakteri Yang terkandung Dalam Udara Berbasis Mikrokontroller Arduino Uno ini bertujuan untuk melakukan sterilisasi ruang perawatan ataupun ruang pelayanan kesehatan lainnya yang terdapat di rumah sakit.
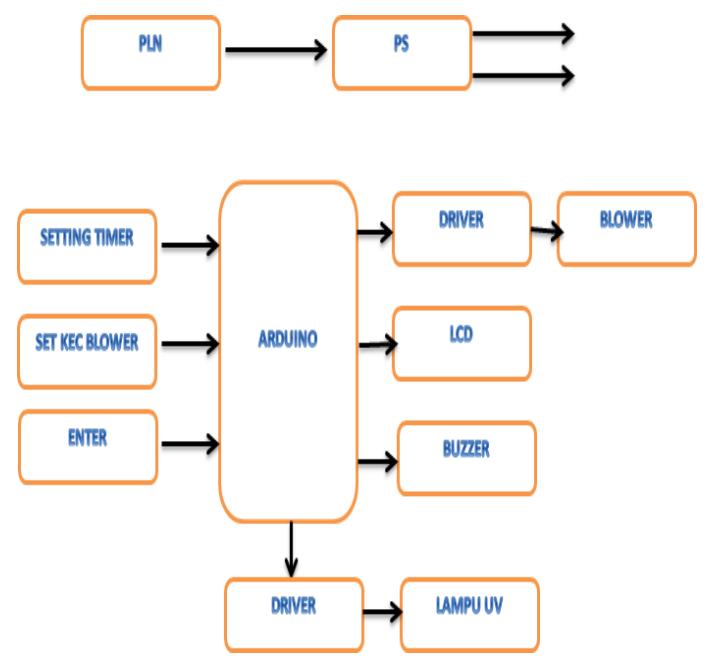

Gambar 3. Blok Diagram desain alat Sterilisator Blok diagram pada gambar 3 menunjukkan bahwa penyettingan waktu digunakan sesuai dengan yang dibutuhkan yaitu 30 menit, 60 
menit . Begitupun kecepatan blower akan disetting sesuai dengan kebutuhan. Data penyetiingan waktu dan kecepatan tersebut akan diolah oleh mikrokontroller Arduino Uno. Keluaran dari Mikrokontroller Uno akan menggerakkan driver untuk mengaktifkan Lampu UV dan Blower.

Penggunaan lampu Ultra Violet (UV) untuk mensterilkan udara yang disimpan dalam sebuah box dan dua buah blower. Blower 1 akan bekerja untuk menghisap udara masuk ke dalam box dan blower 2 akan melepaskan udara tersebut keluar ruangan.

Lamanya waktu pensterilan akan disetting dan ditampilkan pada LCD. Jika waktu penyettingan telah tercapai maka lampu UV akan padam secara otomais dan buzzer akan berbunyi untuk menandakan bahwa ruangan telah selesai di sterilkan.

Adapun gambar flow chart seperti gambar 4.

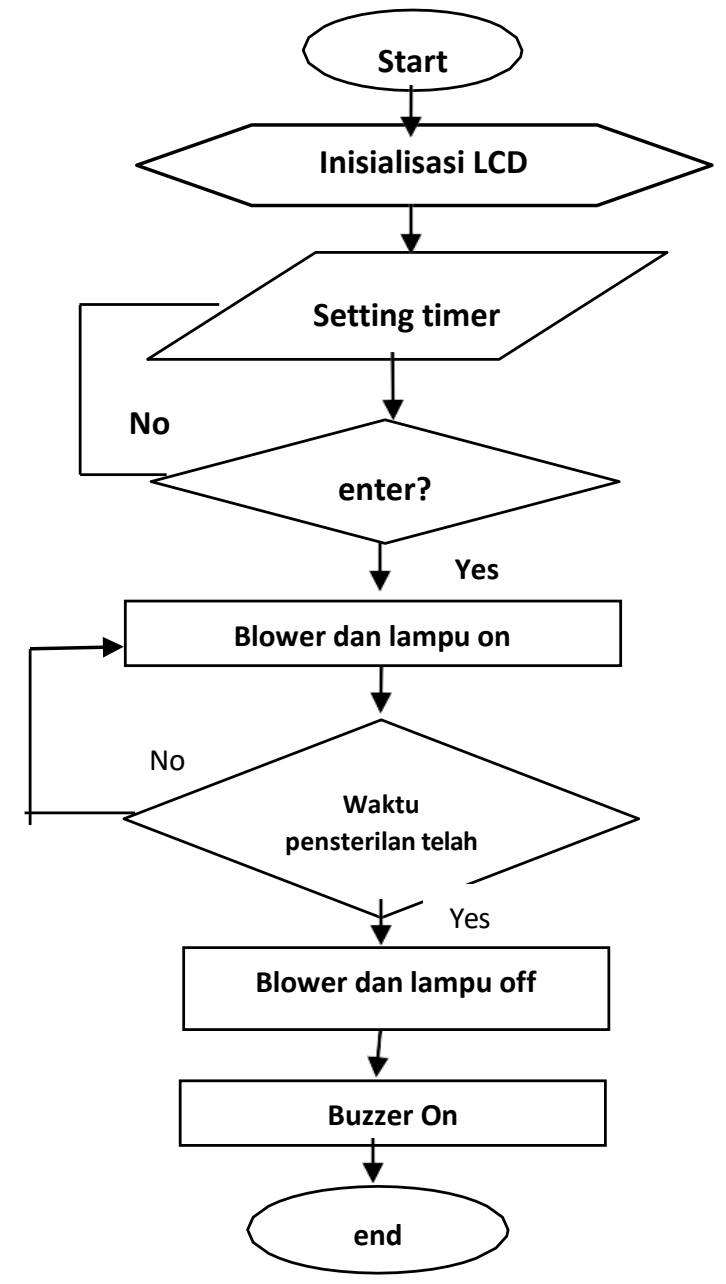

Gambar 4. Flow Chart desain alat Sterilisator

\section{Tempat dan Waktu Penelitian}

Penelitian ini dilakukan di Rumah Sakit St. Khadijah III kota Makassar, dengan periode perencanaan selama 2 (dua) bulan, periode pengembangan model 3 (tiga) bulan dan periode pengujian dan pengambilan data dilakukan selama 2 (dua) bulan dan evaluasi sistem selama 2(dua) bulan, untuk merumuskan hasil dan analissi 1 (satu) bulan dan 2 (dua) bulan untuk dokumentasi dan publikasi.

\section{Hasil Dan Pembahasan}

\section{Perancangan Alat Sterilisator Bakteri dalam Udara}

Pada tahap ini dilakukan proses perancangan alat yang terdiri dari dua bagian yaitu rangkaian lampu UV dan rangkaian control atau sistem control, dari perancangan alat ni dibuat desain alat, bahan dan peralatan yang digunakan seperti : Blower, Rangkaian Mikrokontroller, LCD, Buzer dan lain-lainnya, setelah itu merancang pengontrolannya dengan menggunakan program Arduino Uno seperti yang di tunjukkan gambar 5 .

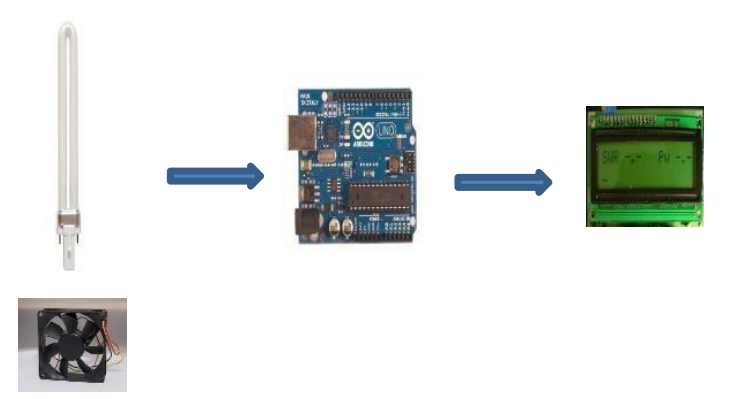

Gambar 5. Rancangan Alat Sterilisator

\section{Pelaksanaan Pembuatan Alat Sterilisator Bakteri dalam Udara}

Proses pembuatan alat Sterilisator Bakteri pada udara dilakukan dengan menggunakan lampu ultraviolet dengan menyetting waktu lamanya pensterilan yang dapat dipantau melalui monitor LCD dan mendeteksi tegangan keluaran dari lampu UV yang digunakan.

Penelitian ini dilaksanakan di laboratorium Elektromedik Poltekkes Muhammadiyah Makassar dan dilakukan Uji coba di RS St.Khadijah III pada bulan Agustus 2019 seperti gambar 6 dan gambar 7. Proses Sterilisasi Bakteri dilakukan dengan mengatur/setting waktu penyinaran lampu Ultraviolet dan hasil 
penyettingan waktu tersebut disbanding langsung dengan alat yang telah terstandarisasi. Dan selama waktu berjalan juga dilakukan pengukuran tegangan keluaran pada lampu ultraviolet.

Adapun hasil pengukuran proses sterilisasi dengan pemberlakuan penyettingan waktu dan pengukuran tegangan pada lampu UV sebanyak tiga kali di ruang Perawatan dan ruang Bedah Rumah Sakit St.Khadijah III. Makassar seperti pada tabel 1 dan tabel 2 :

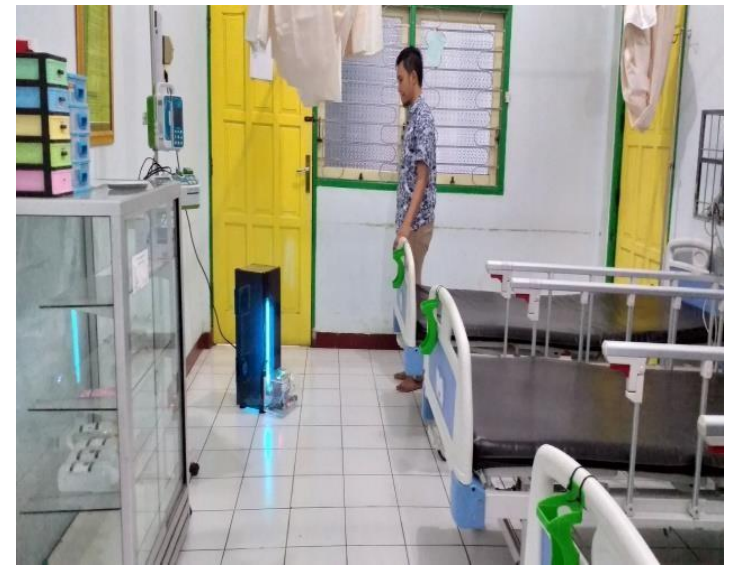

Gambar 6. Pengambilan data alat di Ruang perawatan RSIA Khadijah III

1. Tabel 1. Pada Ruang Perawatan

\begin{tabular}{cccc}
\hline No & Waktu & $\begin{array}{c}\text { Alat berstandar } \\
\text { (menit, detik) }\end{array}$ & $\begin{array}{c}\text { Vo lampu UV } \\
\text { (Volt) }\end{array}$ \\
\hline 1 & 30 & 29,30 & 222 \\
2 & menit & 29,30 & 222 \\
3 & & 29,20 & 221 \\
\hline
\end{tabular}

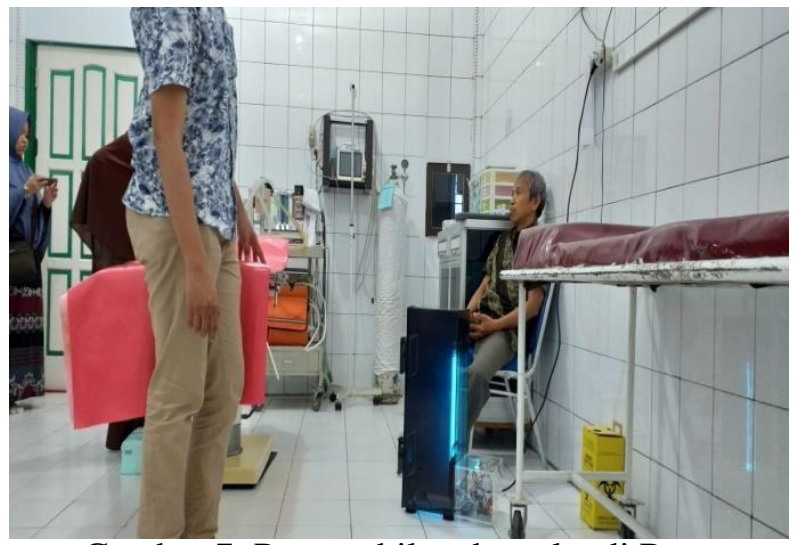

Gambar 7. Pengambilan data alat di Ruang perawatan RSIA Khadijah III

Tabel 2. Pada Ruang Bedah

\begin{tabular}{llcc} 
No Waktu & $\begin{array}{c}\text { Alat berstandar } \\
\text { (menit, detik) }\end{array}$ & $\begin{array}{c}\text { Vo } \\
\text { lampu UV } \\
\text { (Volt) }\end{array}$ \\
\hline
\end{tabular}

\begin{tabular}{lccl}
\hline 1 & \multirow{2}{*}{60} & 59,43 & 223 \\
2 & menit & 59,42 & 222 \\
3 & & 59,42 & 222 \\
\hline
\end{tabular}

\section{Analisa Hasil Penelitian}

Pengukuran waktu yang telah di lakukan beberapa kali dalam melakukan percobaan akan ditentukan beberapa nilai standar deviasi SD, dan error sebagai berikut:

\section{Rata Rata (mean)}

$$
\begin{aligned}
& \text { Rata Rata }(\bar{X})=\frac{\sum X_{n}}{n} \\
& (\bar{X})=\frac{87,8}{3} \\
& (\bar{X})=29,26
\end{aligned}
$$

2. Koreksi (k)

$$
\begin{aligned}
& k=T_{\text {setting }}-T_{\text {rata rata }} \\
& k=30-29,26 \\
& k=0,74
\end{aligned}
$$

3. Kesalahan (Error)

$$
\begin{aligned}
\text { Error } & =\frac{30-29,26}{30} \times 100 \% \\
\text { Error } & =2,4 \%=0,024
\end{aligned}
$$

4. Simpangan rata-rata (SR)

$$
\begin{aligned}
& S R=\frac{\sum x_{n}-\bar{X}}{n} \\
& S R=\frac{29,26-0.74}{29,26} \\
& S R=0,974
\end{aligned}
$$

Jadi berdasarkan hasil analisa statistik adalah rata-rata waktu yang dihasilkan dari penyettingan waktu 30 menit adalah 29,26 menit ,ini menunjukkan penurunan dari waktu yang ditentukan yaitu koreksi sebesar 0,74 menit. Dengan kesalahan (error) sebesar 0,74\%

Analisa data hasil penelitian pada tabel 2. adalah sebagai berikut :

1. Rata Rata (mean)

$$
\begin{aligned}
& \text { Rata Rata }(\bar{X})=\frac{\sum X_{n}}{n} \\
& (\bar{X})=\frac{178,27}{3} \\
& (\bar{X})=59,42
\end{aligned}
$$

2. Koreksi (k)

$$
\begin{aligned}
& k=T_{\text {setting }}-T_{\text {rata rata }} \\
& k=60-59,42,26
\end{aligned}
$$




$$
k=0,57
$$

3. Kesalahan (Error)

$$
\begin{array}{ll}
\text { Error } & =\frac{60-59,42}{60} \times 100 \% \\
\text { Error } & =0,009 \%=0,96
\end{array}
$$

4. Simpangan rata-rata (SR)

$$
\begin{aligned}
S R & =\frac{\sum X_{n}-\bar{X}}{n} \\
S R & =\frac{59,42-0.57}{59,42} \\
S R & =0,99
\end{aligned}
$$

Jadi berdasarkan hasil analisa statistik adalah rata-rata waktu yang dihasilkan dari penyettingan waktu 60 menit adalah 59,42 menit ,ini menunjukkan penurunan dari waktu yang ditentukan yaitu koreksi sebesar 0,57 menit. Dengan kesalahan (error) sebesar 0,96\%

\section{Kesimpulan}

Berdasarkan paparan dan pembahasan hasil penelitian yang disajikan pada bab IV, maka diperoleh kesimpulan sebagai berikut :

1. Peralatan UV Lamp sterilisator digunakan untuk sterilisasi ruangan dengan cara menyinari ruangan dengan cahaya UV yang sangat berbahaya bagi manusia karena dapat mengakibatkan kanker kulit dan kebutaan. Pembuatan Sterilisator bakteri yang terkandung dalam udara berbasis mikrokontroller arduino yang dirancang dengan pengontrolan yaitu menempatkan lampu UV di dalam box sehingga pancaran sinar dari lampu UV tidak ada kontak langsung ke petugas yang mengoperasikan alat tersebut dapat memberi kesempatan kepada operator untuk meninggalkan ruangan

2. Sterilisator bakteri ini dilengkapi dengan dua buah blower untuk menghisap dan melepaskan udara sehingga sirkulasi udara terus berganti sampai udara tersebut steril dari bakteri dan kuman.

3. Hasil analisa statistic pada ruang Perawatan rata-rata waktu yang dihasilkan dari penyettingan waktu 30 menit adalah 29,26 menit, ini menunjukkan penurunan dari waktu yang ditentukan yaitu koreksi sebesar 0,74 menit. dengan kesalahan (error) sebesar 0,74\% . Dan pada ruang Bedah hasil analisa statistic, rata-rata waktu yang dihasilkan dari penyettingan waktu 60 menit adalah 59,42 menit, ini menunjukkan penurunan dari waktu yang ditentukan yaitu koreksi sebesar 0,57 menit. Dengan kesalahan (error) sebesar $0,96 \%$.

4. Hasil ini menunjukkan bahwa Alat sterilisator Bakteri pada udara ini sangat handal digunakan untuk melakukan sterilisasi pada ruang - ruang pelayanan kesehatan yang ada di rumah sakit.

\section{Daftar Pustaka}

[1].Dresbach, Sereana Howard, Wanda Brown. 2008 "Ultraviolet Radiation".. http://ohioline.osu.edu/cdfact/pdf/0199.pdf..Diakses tanggal 4 Juni 2017

[2]. Fauci, Anthony S., dkk, 2008. Harrison's Principles of Internal Medicine. United States: Mc.Graw-Hill.

[3]. Muhammad masykurillah, tahun 2015, "Sterilisasi dan desinfeksi",http://blogspot.co.id/2015/04 diakses tanggal 7 agustus 2017

[4]. Susanto, 1997,"Rangkaian Elektronika Analog dan terpadu",UI Press

[5]. Triwiyanto, 2004"'Tutorial IC Mikrokontroller Arduino Uno

[6]. S.haryati,"Research and development sebagai salah satu model penelitian dalam bidang Pendidikan"2013

[7]. A. Sugiono,"Metode Penelitian Pendidikan pendekatan kumulatif ,Kualitatif R7D tahun 2001 